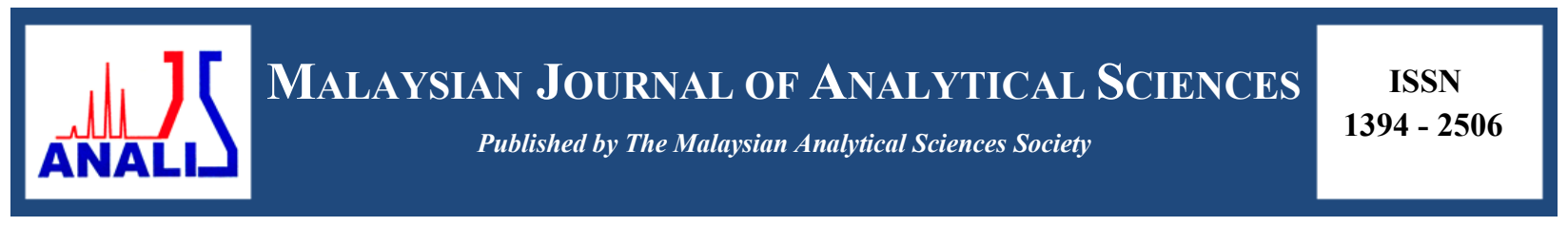

\title{
EFFECT OF INCORPORATING PURPLE-FLESHED SWEET POTATO IN BISCUIT ON ANTIOXIDANT CONTENT, ANTIOXIDANT CAPACITY AND COLOUR CHARACTERISTICS
}

\author{
(Kesan Penambahan Keledek Ungu ke dalam Biskut Terhadap Kandungan Antioksida, Kapasiti \\ Antioksidan dan Ciri-Ciri Warna)
}

\author{
Azni A. Aziz ${ }^{1,3}$, Alyani Mohd Padzil ${ }^{1}$, Ida Idayu Muhamad ${ }^{1,2 *}$ \\ ${ }^{1}$ Bioprocess and Polymer Engineering Department, School of Chemical and Energy Engineering, Faculty of Engineering \\ ${ }^{2}$ Cardiac Biomaterials Cluster, IJN-UTM Cardiovascular Engineering Center, School of Biomedical Engineering \\ and Health Sciences, Faculty of Engineering \\ Universiti Teknologi Malaysia, 81310 Johor Bahru, Johor, Malaysia \\ ${ }^{3}$ Technology and Natural Resources Department, Faculty of Applied Sciences and Technology, \\ Universiti Tun Hussein Onn Malaysia, 86400 Batu Pahat, Johor, Malaysia \\ *Corresponding author: idaidayu@utm.my
}

Received: 16 April 2017; Accepted: 7 April 2018

\begin{abstract}
Purple flesh sweet potato (PFSP) is considered to be a nutritionally rich crop. It also contain abundant amount of anthocyanin pigment which possess disease preventive properties. This work aims to study the effect of incorporating different form of processed PFSP, namely fresh, flour, and paste in biscuit formulation. Analysis was performed on the total phenolic, total anthocyanin content, antioxidant capacity, and colour characteristics. The analyses were made on samples, before and after the incorporation of PFSP in the biscuit. PFSP flour was prepared by directly using hot air-drying at $65^{\circ} \mathrm{C}$ for 18 hours while PFSP paste was steamed for 30 minutes at $100{ }^{\circ} \mathrm{C}$. The PFSP fresh contained total anthocyanin content at $21.40 \mathrm{mg} \mathrm{CyE} / 100 \mathrm{~g} \mathrm{fw}$, and the content increased when processed into the form of flour and paste approximately at $38.90 \mathrm{mg} \mathrm{CyE} / 100 \mathrm{~g} \mathrm{fw}$ and $52.48 \mathrm{mg}$ $\mathrm{CyE} / 100 \mathrm{~g} \mathrm{fw}$, respectively. All forms of processed PFSP enhanced the purple colour when incorporated into the biscuit formulation. The experimental results showed that biscuit added with PFSP lost $15-36 \%$ of antioxidant capacity. Based on these findings, all forms of PFSP can be a natural colourant, a potential functional food ingredient, and can become a superior source for the production of foods with health benefits.
\end{abstract}

Keywords: purple-fleshed sweet potato, biscuit, phenolic, anthocyanin, antioxidant capacity, colour

\section{Abstrak}

Keledek ungu (PFSP) dianggap sebagai tanaman kaya khasiat. Ia juga mengandungi sejumlah besar pigmen antosianin yang mempunyai sifat pencegah penyakit. Kajian ini bertujuan untuk mengkaji kesan penambahan PFSP yang diproses dalam beberapa bentuk berbeza iaitu mentah, tepung, dan pes ke dalam formulasi biskut. Analisis dilakukan terhadap jumlah fenolik, jumlah kandungan antosianin, kapasiti antioksidan, dan ciri-ciri warna. Analisis kajian dijalankan terhadap sampel, sebelum dan selepas PFSP dimasukkan ke dalam biskut. Tepung PFSP disediakan dengan menggunakan pengeringan udara panas pada suhu $65{ }^{\circ} \mathrm{C}$ selama 18 jam manakala pes PFSP dikukus selama 30 minit pada suhu $100{ }^{\circ} \mathrm{C}$. PFSP mentah mengandungi jumlah kandungan antosianin sebanyak $21.40 \mathrm{mg} \mathrm{CyE} / 100 \mathrm{~g}$ fw, dan kandungannya meningkat apabila diproses ke dalam bentuk tepung dan pes iaitu masing-masing sebanyak $38.90 \mathrm{mg} \mathrm{CyE} / 100 \mathrm{~g}$ fw dan $52.48 \mathrm{mg}$ CyE/100g fw. Kesemua bentuk PFSP yang diproses meningkatkan warna ungu apabila dimasukkan ke dalam formulasi biskut. Keputusan eksperimen menunjukkan biskut yang ditambah PFSP hilang kapasiti antioksidan sebanyak 15-36\%. Berdasarkan dapatan ini, semua bentuk PFSP dapat menjadi 
pewarna semula jadi, berpotensi sebagai bahan makanan berfungsi, dan boleh menjadi sumber penting untuk pengeluaran makanan dengan manfaat kesihatan.

Kata kunci: keledek ungu, biskut, fenolik, antosianin, kapasiti antioksidan, warna

\section{Introduction}

In recent years, interest on functional food or ingredients are increasing due to the rise in health conscious among consumers. Sweet potatoes are rich in vitamins B1, B2, C, and E; minerals such as calcium, magnesium, potassium and zinc; dietary fibre, and non-fibrous carbohydrates. There are many varieties of sweet potato available in the market. Sweet potato could be utilized in products to improve the colour, flavour, and nutrients content. In particular, anthocyanin can be found in abundant inside the purple-fleshed sweet potato varieties compared to other coloured-fleshed ones. The sweet potato roots exhibit the purple colour due to the build-up of anthocyanin as pigments. The sensory profiling for the purple sweet potatoes are characterized as fibrous visually and have chalky, dense, firm texture. The taste is characterised as of white baked potato flavour and vanilla aroma [1].

Previous research findings by Kim et al. [2] and Teow et al. [3] indicated that purple-fleshed sweet potato has higher antioxidant activities compared to other coloured-fleshed sweet potato. This is caused by the presence of anthocyanins and phenolic compounds in the storage roots. The anthocyanin is found to exhibit medical advantages, including reducing coronary illness and stroke, cancer-causing agent activity, anti-inflammatory effects, enhanced visual sharpness, and enhanced cognitive conduct $[4,5]$. However, sweet potato is highly perishable and difficult to store. Thus, sweet potato can be processed into flour [6-8] and paste or puree [9-11], which could be incorporated into different appealing products for consumers, such as snacks, pasta, pancake, bread, and cookies.

Food can act as a vehicle to deliver bioactive and micronutrients at a suitable level. This is evidenced in a study by Chan et al. [12] which demonstrated an increment extraction yield, total phenolic substance, total flavonoid substance, and antioxidant capacity, showing that sweet potato flour bioactive compound could be stable in the gastrointestinal tract as their active component may be held and enhanced in the food. However, in creating a functional bakery product, it is essential to understand that a quality functional food not only to include the functional ingredients, but it must also meet consumers' necessities such as appearance, taste, and composition [13].

The main objectives of this study are (a) to determine the total phenolic, anthocyanin content, and antioxidant capacity of different PFSP forms, namely fresh, flour, and paste; (b) to compare the antioxidant content and capacity, before and after addition in biscuit formulation; and (c) to measure the colour characteristic of different PFSP forms and in biscuit, which will provide valuable information in utilizing PFSP in other formulated product.

\section{Materials}

\section{Materials and Methods}

The chemicals used in this study were of analytical grade, which includes acetone, chloroform, hydrochloric acid, Folin-Ciocalteu reagent, gallic acid, sodium carbonate, potassium chloride, sodium acetate, glacial acetic acid, methanol, 2,4,6-tri[2-pyridyl]-s-triazine (TPTZ), ferric chloride $\left(\mathrm{FeCl}_{3} \cdot 6 \mathrm{H}_{2} \mathrm{O}\right)$, ferrous sulphate $\left(\mathrm{FeSO}_{4} \cdot 7 \mathrm{H}_{2} \mathrm{O}\right)$, and 1,1-diphenyl-2-picrylhydrazyl (DPPH). The purple-fleshed sweet potato were purchased at a local market in Johor Bahru, Malaysia. Commercially available ingredients for biscuit formulation: wheat flour, butter, sugar, salt, and skim milk powder were purchased from a bakery shop in Johor Bahru.

\section{Preparation of fresh, flour, and paste from purple-fleshed sweet potato}

The three forms of PFSP were prepared by manually washing, peeling, and cutting into thin slices of $2 \mathrm{~mm}$ thick. PFSP fresh slices were further shredded into small pieces. PFSP flour was processed by directly using hot air-drying at $65{ }^{\circ} \mathrm{C}$ for 18 hours, finely ground using a commercial blender (Philips, Malaysia), and sieved through an 80 -mesh (Retsch, Germany) screen to obtain uniform-size. The flours were then packed in polypropylene bags and stored at 5-10 ${ }^{\circ} \mathrm{C}$ until further use. Meanwhile, PFSP paste was made by steaming for 30 minutes at $100{ }^{\circ} \mathrm{C}$, cooled, and mashed into paste. 


\section{Biscuit formulation}

$200 \mathrm{~g}$ wheat flour, $84 \mathrm{~g}$ sugar, $80 \mathrm{~g}$ butter, $2.5 \mathrm{~g}$ salt, and $2 \mathrm{~g}$ skim milk powder were used as the biscuit formulation. PFSP was incorporated at $30 \%$ flour weight basis. The butter and sugar was creamed, then salt, skim milk powder and water was added. Finally, the PFSP and wheat flour were mixed until uniform. The dough was rolled out at $5 \mathrm{~mm}$ thick and pressed using a $5 \mathrm{~mm}$ round cutter. The biscuit were then baked at $160{ }^{\circ} \mathrm{C}$ for 20 minutes in an electric oven (OT52R, Khind, Malaysia), cooled, and stored in a zip lock bag for further analysis. The analysis was performed on both conditions, before and after incorporation of PFSP in biscuit.

\section{Extraction}

Extraction of samples was performed as described by Rodriguez-Saona and Wrolstad [14]. The samples were freeze-dried (Alpha 1-2LD Plus, Martin Christ, Germany) at $-50{ }^{\circ} \mathrm{C}$ for 12 hours. An amount of $50 \mathrm{~g}$ of the freezedried sample were weighed into a conical flask and mixed with $70 \%$ aqueous acetone $1: 2(\mathrm{w} / \mathrm{v})$ by stirring for 15 minutes. The extract (filtrate) was obtained by filtering through Whatman No. 1 filter paper. The procedure was repeated thrice until a faintly coloured solution was attained. The filtrate was then transferred into a separating funnel and chloroform 1:2(v/v) was added and gently mix until there is a clear partition between the two phases. The upper portion was then transferred into a rotary evaporator at $40^{\circ} \mathrm{C}$ to remove the solvent residue and made up to $100 \mathrm{~mL}$ with acidified distilled water. The extraction was poured in a sample bottle and kept at $4{ }^{\circ} \mathrm{C}$ until further use. Duplicate extractions were made for each sample.

\section{Total phenolic content}

Total phenolic content was measured by Folin-Ciocalteu method [15]. Briefly, $20 \mu \mathrm{L}$ of the sample extract was respectively mixed with $1.58 \mathrm{~mL}$ water, followed by $100 \mu \mathrm{L}$ Folin-Ciocalteu reagent in a $1 \mathrm{~cm}, 2 \mathrm{~mL}$ plastic cuvette and incubated for 5 minutes. Then, $300 \mu \mathrm{L}$ sodium carbonate solution was added, mixed, and incubated for 2 hours at room temperature. The sample was observed at $765 \mathrm{~nm}$ using a UV- Spectrophotometer (Jenway 7305 Spectrophotometer, USA). Gallic acid was used as a standard and the results was expressed as milligram of gallic acid equivalent (mg GAE/100g fw).

\section{Total monomeric anthocyanin content}

Total monomeric anthocyanin content was determined by using $\mathrm{pH}$ differential method [16]. Two $0.3 \mathrm{~mL}$ sample extracts were prepared for dilution. One was added with $2.7 \mathrm{~mL}$ potassium chloride buffer, $\mathrm{pH} 1.0$ and another one was added with $2.7 \mathrm{~mL}$ sodium acetate buffer, $\mathrm{pH} 4.5$. The sample was left to equilibrate for 15 minutes before using a UV-Spectrophotometer (Jenway 7305 Spectrophotometer, USA) to read the absorbance at $510 \mathrm{~nm}$ and 700 $\mathrm{nm}$. Difference in absorbance between $\mathrm{pH}$ values and wavelengths were calculated using the following equation 1 :

$$
A=\left(A_{510 \mathrm{~nm}}-\mathrm{A}_{700 \mathrm{~nm}}\right) \mathrm{pH}_{1.0}-\left(\mathrm{A}_{510 \mathrm{~nm}}-\mathrm{A}_{700 \mathrm{~nm}}\right) \mathrm{pH}_{4.5}
$$

Meanwhile, concentration of monomeric anthocyanin pigment can be calculated as follows (equation 2):

$$
\text { Monomeric anthocyanin pigment }(\mathrm{mg} / \mathrm{L})=(\mathrm{A} \times \mathrm{MW} \times \mathrm{DF} \times 1000) \div(\varepsilon \times 1)
$$

where, MW is the molecular weight of Cyanidin-3-glucoside (MW $=449.2), \varepsilon$ is the molar absorptivity $(\varepsilon=26900)$, $\mathrm{DF}$ is the dilution factor, and 1 is for standard $1 \mathrm{~cm}$ path length. Results were expressed as $\mathrm{mg}$ cyanidin-3-glucoside equivalent ( $\mathrm{mg} \mathrm{CyE} / 100 \mathrm{~g} \mathrm{fw}$ ) because it is predominantly found in sweet potato.

\section{Antioxidant capacity}

Ferric Reducing Antioxidant Power (FRAP) was measured using a method adapted from Benzie and Strain [17]. In brief, $30 \mu \mathrm{L}$ of sample extract was added into $1 \mathrm{~mL}$ of FRAP reagent $(300 \mathrm{mM}$ acetate buffer $\mathrm{pH} 3.6,10 \mathrm{mM}$ TPTZ in $40 \mathrm{mM} \mathrm{HCl}$ and $20 \mathrm{mM} \mathrm{FeCl}_{3}$ at a ratio of 10:1:1). The mixture was left for 4 minutes and the absorbance was read at $593 \mathrm{~nm}$ using a UV-Visible spectrophotometer (Jenway 7305 Spectrophotometer, USA). Ferrous sulphate $\left(\mathrm{FeSO}_{4} \cdot 7 \mathrm{H}_{2} \mathrm{O}\right)$ was used as a standard and FRAP was expressed as $\mathrm{mg} \mathrm{Fe} / \mathrm{g}$ fw.

The $\mathrm{DPPH}^{*}$ radical scavenging assay was performed as described by Brand-Willams et al. [18] with a slight modification by mixing $0.2 \mathrm{~mL}$ of sample extract added with $1.8 \mathrm{~mL}$ of methanol and $2 \mathrm{~mL} \mathrm{DPPH}(0.06 \mathrm{mM})$ in 
methanol solution. The reaction mixtures were kept at room temperature in the dark for 30 minutes. The absorbance was measured at $517 \mathrm{~nm}$ using UV-Spectrophotometer (Jenway 7305 Spectrophotometer, USA). Antioxidant activity (\%) by the DPPH free radical was calculated by using the following formula:

$$
\text { Antioxidative activity }(\%)=\frac{A_{b}-A_{s}}{A_{b}} \times 100
$$

where, $A_{b}$ is the absorbance of blank (DPPH only) and $A_{s}$ is the absorbance of sample.

\section{Colour analysis}

The colour of the samples was measured using a colorimeter (Konica Minolta, Japan) adopting CIE L*a*b* colour system and set with a D65 illuminant at $10^{\circ}$. The $\mathrm{L}^{*}$ represents lightness, $\mathrm{a}^{*}$ express $(+)$ red or $(-)$ green, and $\mathrm{b}^{*}$ express $(+)$ yellow or $(-)$ blue. The chroma $\left(C^{*}\right)$ and hue angle $\left(h^{*}\right)$ was calculated by $\left[a^{* 2}+b^{*^{2}}\right]^{1 / 2}$ and arctan $\left(b^{*} / a^{*}\right)$ respectively from the $a^{*}$ and $b^{*}$ values. $C^{*}$ represents the difference in saturation $(+)$ brighter and $(-)$ duller while $\mathrm{h}^{*}$ indicates colour hue, where the units are in the form of degrees, ranging from $0^{\circ}$ (red), $60^{\circ}$ (yellow), $120^{\circ}$ (green), $180^{\circ}$ (cyan), $240^{\circ}$ (blue), $300^{\circ}$ (magenta), and back to $0^{\circ}$. The final data were averaged from six replications.

\section{Statistical analysis}

Analysis of variance (ANOVA) was carried out to determine and compare the significance of differences between means (comparison between means of samples). The results are shown as mean \pm standard deviation of mean. The level of significance was set at $\mathrm{p}<0.05$.

\section{Results and Discussion}

\section{Effect of different PFSP forms and its incorporation in biscuit on antioxidant content}

As shown in Table 1, phenolic content in PFSP fresh is $76.70 \mathrm{mg}$ GAE/100 g fw. After steaming into PFSP paste, the phenolic content increased nearly twice higher than the fresh sample. However, drying PFSP into flour did not show any significant difference compared to fresh sample. Cell structure was broken and ruptured during steaming which resulted in more components expressed from the tuber. Drying also released more bound phenolic from breakdown of cellular structure due to thermal treatment [19]. When incorporated in biscuit, the PFSP paste loss the most amount of total phenolic at $70 \%$, while the PFSP fresh and flour at $46 \%$ and 33\%, respectively. Substantial reduction in phenolic content was probable due to a cell rupture causing leaching into water, degradation from processing and oxidation by polyphenol oxidase [20].

Table 1. The total phenolic content and total anthocyanin content (means \pm standard deviation) of different form of purple-fleshed sweet potato and its incorporation in biscuit

\begin{tabular}{lcc}
\hline & $\begin{array}{c}\text { Total Phenolic Content } \\
\text { (mg GAE/100g fw) }\end{array}$ & $\begin{array}{c}\text { Total Anthocyanin Content } \\
\text { (mg CyE/100g fw) }\end{array}$ \\
\hline PFSP Fresh & $76.70 \pm 1.24^{\mathrm{a}}$ & $21.40 \pm 0.25^{\mathrm{a}}$ \\
PFSP Flour & $80.89 \pm 1.58^{\mathrm{a}}$ & $38.90 \pm 0.34^{\mathrm{b}}$ \\
PFSP Paste & $118.27 \pm 2.77^{\mathrm{b}}$ & $52.48 \pm 0.10^{\mathrm{c}}$ \\
\hline Incorporation in Biscuit & & - \\
Control & $23.97 \pm 0.14^{\mathrm{a}}$ & $3.55 \pm 0.26^{\mathrm{a}}$ \\
PFSP Fresh & $41.07 \pm 0.28^{\mathrm{b}}$ & $10.81 \pm 0.10^{\mathrm{b}}$ \\
PFSP Flour & $54.39 \pm 0.88^{\mathrm{c}}$ & $4.14 \pm 0.13^{\mathrm{c}}$ \\
PFSP Paste & $35.00 \pm 0.29^{\mathrm{d}}$ & \\
\hline
\end{tabular}

$\mathrm{a}, \mathrm{b}, \mathrm{c}$ means with different letter(s) in the same column differed significantly $(\mathrm{p}<0.05)$ 
PFSP paste had the highest total anthocyanin content at $52.48 \mathrm{mg} C \mathrm{Cy} / 100 \mathrm{~g}$ fw which was twice higher than the PFSP fresh. The results suggest that steaming of PFSP into paste inactivate enzymes that degrade anthocyanin pigments and other antioxidant compounds. This showed that PFSP fresh are a good source of anthocyanins and the level of these compounds increased when processed in different form. Anthocyanins found in this type of sweet potato exhibit more stability as compared to those in strawberry, raspberry, apple, and soybean with black seed coat with a low level of acylation [5]. Discoveries of acylated anthocyanins with better stability demonstrated that these colours may be more desirable in food product [21].

The antioxidant of a food matrix is likely to be enhanced when another functional ingredient is incorporated or substituted. As seen, after incorporation in biscuit formulation the anthocyanin content was still available where biscuit with PFSP flour (10.81 mg CyE/100 g fw) had the retention more than twice as compared to biscuit with PFSP fresh and paste. The stability of antioxidant compound anthocyanin in food processing could be seen in a study of biscuit production with added anthocyanin extract from red and black berries mix, sour cherries, grape, and pressed grape marc. The anthocyanin content in the baked cookies contained $103 \times 10^{-3} \mathrm{~g} \mathrm{CyCl} / \mathrm{kg}$ product. Considered that the mean weight of biscuits was about $8 \mathrm{~g}$, five biscuits supply for about $4 \times 10^{-3} \mathrm{~g}$ anthocyanins, similarly to the most marketed food supplements, that contain $2 \times 10^{-3}-18 \times 10^{-3} \mathrm{~g}$ anthocyanins per dose [22].

\section{Effect of different PFSP form and its incorporation in biscuit on antioxidant capacity}

Ferric reducing power indicate the ability of natural antioxidant to donate electrons. Table 2 shows the FRAP values of the antioxidant extract of PFSP. PFSP paste had the highest reducing power (148.19 $\mathrm{g} \mathrm{Fe} / \mathrm{g} \mathrm{fw})$, while PFSP fresh exhibited the lowest power ( $85.97 \mathrm{~g} \mathrm{Fe} / \mathrm{g} \mathrm{fw})$ among all three forms. The PFSP flour and PFSP paste had significantly higher FRAP value $130.72 \mathrm{~g} \mathrm{Fe} / \mathrm{g}$ fw and $148.19 \mathrm{~g}$ Fe/g fw, respectively than the PFSP fresh samples, indicating that the reducing power in sweet potato was increased by thermal process [23]. Meanwhile, further thermal processing on biscuit causes the antioxidant capacity to be significantly reduced. The highest antioxidant capacity is biscuit with PFSP flour (28.64 g Fe/g fw), whereas the lowest is in biscuit with PFSP fresh $(9.73 \mathrm{~g} \mathrm{Fe} / \mathrm{g}$ fw). However, all biscuits with PFSP incorporated showed a significant increase in antioxidant capacity as compared to control biscuit at $1.21 \mathrm{~g} \mathrm{Fe} / \mathrm{g}$ fw. This suggests that not only PFSP contribute to the colour of the biscuit, it also enhances the antioxidant capacity.

Table 2. The antioxidant capacity (means \pm standard deviation) of different form purple-fleshed sweet potato incorporated in biscuit

\begin{tabular}{lcc}
\hline & $\begin{array}{c}\text { FRAP } \\
(\mathbf{m g ~ F e} / \mathbf{g} \text { fw) }\end{array}$ & $\begin{array}{c}\text { DPPH } \\
(\mathbf{\%})\end{array}$ \\
\hline PFSP Fresh & $85.97 \pm 3.42^{\mathrm{a}}$ & $84.78 \pm 0.37^{\mathrm{a}}$ \\
PFSP Flour & $130.72 \pm 3.40^{\mathrm{b}}$ & $86.46 \pm 0.26^{\mathrm{b}}$ \\
PFSP Paste & $148.19 \pm 2.19^{\mathrm{c}}$ & $92.07 \pm 0.65^{\mathrm{c}}$ \\
\hline Incorporation in Biscuit & & \\
Control & $1.21 \pm 0.06^{\mathrm{a}}$ & $35.40 \pm 1.05^{\mathrm{a}}$ \\
PFSP Fresh & $9.73 \pm 0.04^{\mathrm{b}}$ & $54.12 \pm 0.52^{\mathrm{b}}$ \\
PFSP Flour & $28.64 \pm 0.27^{\mathrm{c}}$ & $73.82 \pm 0.71^{\mathrm{c}}$ \\
PFSP Paste & $16.39 \pm 0.16^{\mathrm{d}}$ & $64.12 \pm 0.71^{\mathrm{d}}$ \\
\hline
\end{tabular}

$\mathrm{a}, \mathrm{b}, \mathrm{c}, \mathrm{d}$ means with different letter(s) in the same column differed significantly $(\mathrm{p}<0.05)$ 
There was significant difference in DPPH values among all forms of PFSP and when incorporated in biscuit as shown in Table 2. Obviously, the sample before being added in biscuit exhibits a higher radical scavenging activity between $84-92 \%$ in all forms. However, when incorporated in biscuit, PFSP paste suffered about $30 \%$ loss of antioxidant capacity. In comparison with PFSP flour in biscuit, only $15 \%$ lost in antioxidant capacity. PFSP fresh in biscuit has the lowest antioxidant capacity of $54.12 \%$ followed by PFSP paste $64.12 \%$, and PFSP flour $73.82 \%$. A study by previous researcher [24], showed that purple sweet potato demonstrated stronger DPPH radical-scavenging activities as compared to other commercial food pigments of the anthocyanidin family. DPPH radical scavenging activity can be contributed by the presence of anthocyanin or phenolic compound depending on the type of purple sweet potato cultivar. As demonstrated in a comparative study, the radical scavenger in cultivar Ayamurasaki and Kyushu-132 are dominantly contributed by anthocyanin while the cultivar of Miyanou-36 and Bise are from phenolic compounds [25]. This observation is supported by another study which showed that the antioxidant activity by sweet potato not only come from anthocyanins but also from an additive effect with hydroxycinnamic acids [26].

\section{Effect of different PFSP form and its incorporation in biscuit on colour characteristics}

The colour values are presented in Table 3 where PFSP fresh, flour, and paste exhibited hue angles of a purple (magenta) colour due to the rich accumulation of anthocyanins in the flesh of the storage roots. Analysis using HPLC-DAD/ESI-MS/MS on purple sweet potato concluded that the cyanidin and peonidin that contribute to the blue and red hue are the major contributor anthocyanin pigment colour found in purple-fleshed [27]. PFSP paste showed significantly lower $\mathrm{L}^{*}$ value which is the darkest colour among all form. Inversely, when added in biscuit, PFSP flour had the lowest $L^{*}$ value. All forms of PFSP lost its negative $b^{*}$ value when incorporated in biscuit formulation. The difference in $\mathrm{a}^{*}$ and $\mathrm{b}^{*}$ values may be contributed to the amount of phenolic and anthocyanin content present [28]. When incorporated in biscuit, the hue angle was towards red colour and control biscuit exhibit a hue angle towards yellow colour as seen in a digital picture in Figure 1. The considerable changes of colour value in different forms of PFSP incorporated in biscuit was attributed to the degradation of anthocyanin during processing and baking [23].

Table 3. The colour characteristic (means \pm standard deviation) of different form purple-fleshed sweet potato incorporated in biscuit

\begin{tabular}{lccccc}
\hline & $\mathbf{L}^{*}$ & $\mathbf{a}^{*}$ & $\mathbf{b}^{*}$ & $\begin{array}{c}\text { Chroma } \\
\left(\mathbf{C}^{*}\right)\end{array}$ & $\begin{array}{c}\text { Hue angle } \\
\left(\mathbf{h}^{*}\right)\end{array}$ \\
\hline PFSP Fresh & $32.77 \pm 1.39^{\mathrm{a}}$ & $30.63 \pm 1.71^{\mathrm{a}}$ & $-9.47 \pm 1.07^{\mathrm{a}}$ & 32.06 & 342.82 \\
PFSP Flour & $61.22 \pm 0.78^{\mathrm{b}}$ & $17.23 \pm 0.31^{\mathrm{b}}$ & $-0.23 \pm 0.16^{\mathrm{b}}$ & 17.23 & 359.24 \\
PFSP Paste & $27.08 \pm 0.63^{\mathrm{c}}$ & $17.43 \pm 0.40^{\mathrm{b}}$ & $-7.12 \pm 0.19^{\mathrm{c}}$ & 18.83 & 337.78 \\
\hline Incorporation in Biscuit & & & & \\
Control & $75.40 \pm 0.46^{\mathrm{a}}$ & $2.88 \pm 0.34^{\mathrm{a}}$ & $31.03 \pm 0.61^{\mathrm{a}}$ & 31.16 & 84.71 \\
PFSP Fresh & $62.93 \pm 1.58^{\mathrm{b}}$ & $12.36 \pm 1.16^{\mathrm{b}}$ & $15.45 \pm 1.43^{\mathrm{b}}$ & 19.79 & 51.35 \\
PFSP Flour & $48.66 \pm 0.68^{\mathrm{c}}$ & $20.94 \pm 0.63^{\mathrm{c}}$ & $9.71 \pm 0.69^{\mathrm{c}}$ & 23.08 & 24.89 \\
PFSP Paste & $59.46 \pm 0.57^{\mathrm{d}}$ & $15.69 \pm 0.88^{\mathrm{d}}$ & $11.09 \pm 2.58^{\mathrm{c}}$ & 19.21 & 35.26 \\
\hline
\end{tabular}

$\mathrm{a}, \mathrm{b}, \mathrm{c}, \mathrm{d}$ Means with different letter(s) in the same column differed significantly $(\mathrm{p}<0.05)$ 

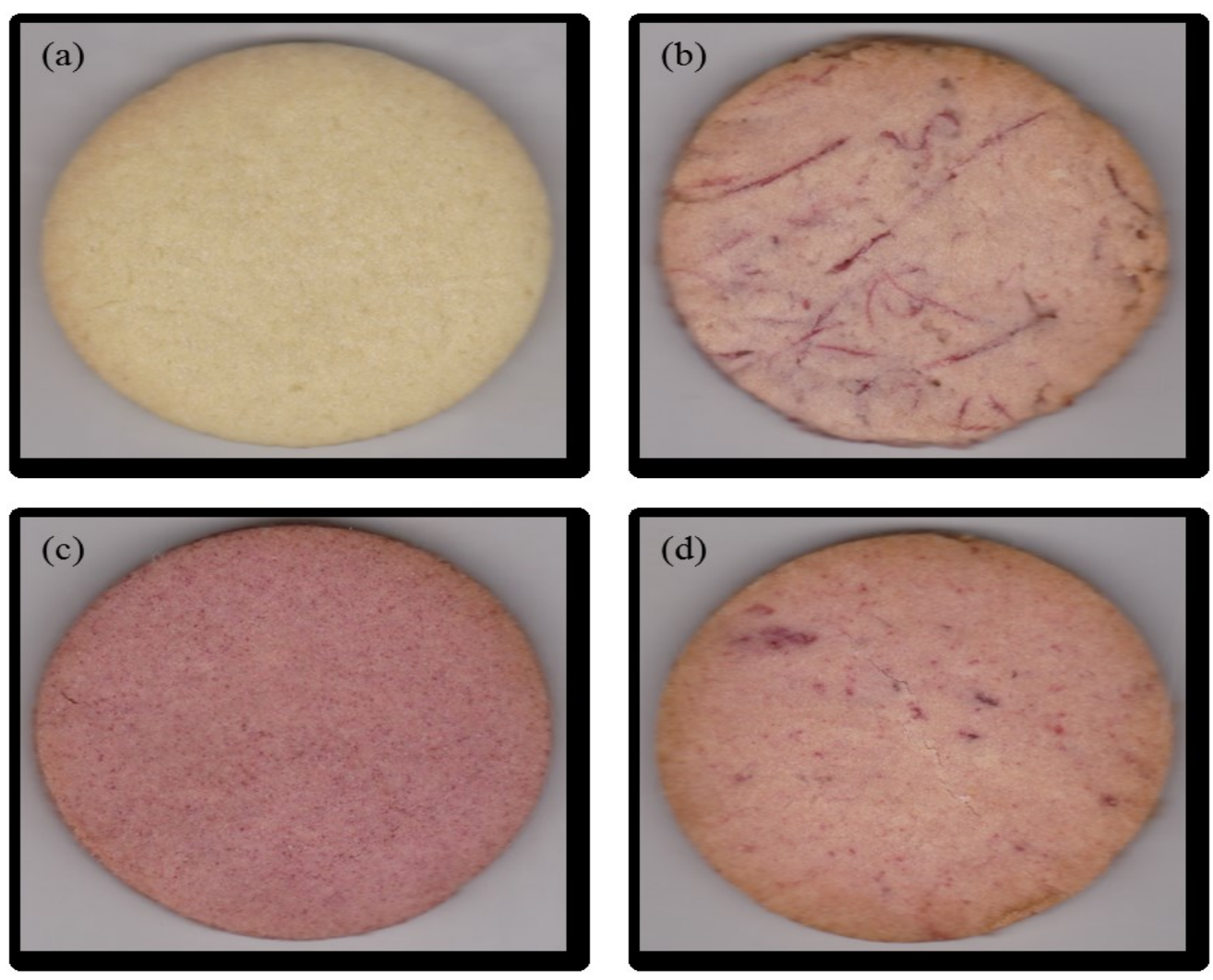

Figure 1. Biscuit incorporated with 30\% different form PFSP. (a) Control, (b) PFSP fresh biscuit, (c) PFSP flour biscuit, (d) PFSP paste biscuit

\section{Conclusion}

Incorporation of any form of PFSP in biscuit not only produce a more attractive biscuit in terms of colour. It also add an additional content of phenolic and anthocyanin which significantly showed a higher antioxidant capacity compared to control biscuit, especially in PFSP flour form. Thus, more products utilizing purple flesh sweet potato could be commercialized in the near future and exert their health benefits by helping prevent lifestyle chronic disease.

\section{Acknowledgement}

The authors would like to thank Universiti Teknologi Malaysia (UTM), Universiti Tun Hussein Onn Malaysia (UTHM), Ministry of Higher Education (MOHE), Research Management Centre (RMC), UTM for their financial support of this work through the project number Q. J130000.3044.00M80 and R. J130000.7809.4F343 for their financial support of this work.

\section{References}

1. Leksrisompong, P. P., Whitson, M. E., Truong, V. D. and Drake, M. A. (2012). Sensory attributes and consumer acceptance of sweet potato cultivars with varying flesh colour. Journal of Sensory Studies, 27 (1): 59-69.

2. Kim, J. M., Park, S. J., Lee, C. S., Ren, C., Kim, S. S. and Shin, M. (2011). Functional properties of different korean sweet potato varieties. Food Science and Biotechnology, 20(6): 1501-1507.

3. Teow, C. C., Truong, V. D., McFeeters, R. F., Thompson, R. L., Pecota, K. V. and Yencho, G. C. (2007). Antioxidant activities, phenolic and $\beta$-carotene contents of sweet potato genotypes with varying flesh colours. Food Chemistry, 103(3): 829-838. 
4. Wrolstad, R. (2006). Anthocyanin pigments-bioactivity and coloring properties. Journal of Food Science, 69(5): 419-425.

5. Suda, I., Oki, T., Masuda, M., Kobayashi, M., Nishiba, Y. and Furuta, S. (2003). Physiological functionality of purple-fleshed sweet potatoes containing anthocyanins and their utilization in foods. Japan Agricultural Research Quarterly, 37(3): 167-173.

6. Greene, J. L. and Bovell-Benjamin, A. C. (2004). Macroscopic and sensory evaluation of bread supplemented with sweet-potato flour. Journal of Food Science, 69(4): 167-173.

7. Huang, Y. C., Chang, Y. H. and Shao, Y. Y. (2006). Effects of genotype and treatment on the antioxidant activity of sweet potato in Taiwan. Food Chemistry, 98(3): 529-538.

8. Ruttarattanamongkol, K., Chittrakorn, S., Weerawatanakorn, M. and Dangpium, N. (2015). Effect of drying conditions on properties, pigments and antioxidant activity retentions of pretreated orange and purple-fleshed sweet potato flours. Journal of Food Science and Technology, 53(4): 1811-1822.

9. Wu, K. L., Sung, W. C. and Yang, C. H. (2009). Characteristics of dough and bread as affected by the incorporation of sweet potato paste in the formulation. Journal of Marine Science and Technology, 17(1): 1322.

10. Steed, L. E. and Truong, V. D. (2008). Anthocyanin content, antioxidant activity, and selected physical properties of flowable purple-fleshed sweetpotato purees. Journal of Food Science, 73(5): 215-221.

11. Ginting, E. and Yulifianti, R. (2015). Characteristics of noodle prepared from orange-fleshed sweet potato, and domestic wheat flour. Procedia Food Science, 3: 289-302.

12. Chan, K. W., Khong, N. M. H., Iqbal, S., Umar, I. M. and Ismail, M. (2012). Antioxidant property enhancement of sweet potato flour under simulated gastrointestinal pH. International Journal of Molecular Sciences, 13: $8987-8997$.

13. Siró, I., Kápolna, E., Kápolna, B. and Lugasi, A. (2008). Functional food. product development, marketing and consumer acceptance- A review. Appetite, 51(3): 456-467.

14. Rodriguez-Saona, L. E. and Wrolstad, R. E. (2001). Extraction, isolation, and purification of anthocyanins. In Current Protocols in Food Analytical Chemistry. Hoboken, NJ, USA: John Wiley \& Sons, Inc. F1.1.1 F1.1.11.

15. Waterhouse, A. L. (2003). Determination of total phenolics. In Current Protocols in Food Analytical Chemistry. Hoboken, NJ, USA: John Wiley \& Sons, Inc. I1.1.1 - I1.1.8.

16. Giusti, M. M. and Wrolstad, R. E. (2001). Characterization and measurement of anthocyanins by UV-visible spectroscopy. In Current Protocols in Food Analytical Chemistry. Hoboken, NJ, USA: John Wiley \& Sons, Inc. F1.2.1 - F1.2.13.

17. Benzie, I. F. F. and Strain, J. J. (1996). The ferric reducing ability of plasma (FRAP) as a measure of "antioxidant power": The FRAP assay. Analytical Biochemistry, 239 (1): 70-76.

18. Brand-Williams, W., Cuvelier, M. E. and Berset, C. (1995). Use of a free radical method to evaluate antioxidant activity. LWT - Food Science and Technology, 28(1): 25-30.

19. Yang, J., Chen, J., Zhao, Y. and Mao, L. (2010). Effects of drying processes on the antioxidant properties in sweet potatoes. Agricultural Sciences in China, 9(10): 1522-1529.

20. Takenaka, M., Nanayama, K., Isobe, S. and Murata, M. (2006). Changes in caffeic acid derivatives in sweet potato (Ipomoea batatas L.) during cooking and processing. Bioscience, Biotechnology, and Biochemistry, 70(1): 172-177.

21. Giusti, M. M. and Wrolstad, R. E. (2003). Acylated anthocyanins from edible sources and their applications in food systems. Biochemical Engineering Journal, 14(3): 217-225.

22. Pasqualone, A., Bianco, A. M., Paradiso, V. M., Summo, C., Gambacorta, G., Caponio, F. and Blanco, A. (2015). Production and characterization of functional biscuits obtained from purple wheat. Food Chemistry, 180: 64-70.

23. Tang, Y., Cai, W. and Xu, B. (2015). Profiles of phenolics, carotenoids and antioxidative capacities of thermal processed white, yellow, orange and purple sweet potatoes grown in Guilin, China. Food Science and Human Wellness, 4 (3): 123-132.

24. Kano, M., Takayanagi, T., Harada, K., Makino, K. and Ishikawa, F. (2005). Antioxidative activity of anthocyanins from purple sweet potato, Ipomoera batatas cultivar ayamurasaki. Bioscience, Biotechnology, and Biochemistry, 69(5): 979-988. 
25. Oki, T., Masuda, M., Furuta, S., Nishiba, Y., Terahara, N. and Suda, I. (2002). Involvement of anthocyanins and other phenolic compounds in radical-scavenging activity of purple-fleshed sweet potato cultivars. Journal of Food Science, 67(5): 1752-1756.

26. Philpott, M., Gould, K. S., Lim, C. and Ferguson, L. R. (2004). In situ and in vitro antioxidant activity of sweetpotato anthocyanins. Journal of Agricultural and Food Chemistry, 52(6): 1511-1513.

27. Truong, V. D., Deighton, N., Thompson, R. T., McFeeters, R. F., Dean, L. O., Pecota, K. V. and Yencho, G. C. (2010). Characterization of anthocyanins and anthocyanidins in purple-fleshed sweetpotatoes by HPLCDAD/ESI-MS/MS. Journal of Agricultural and Food Chemistry, 58(1): 404-410.

28. Yang, J. and Gadi, R. L. (2008). Effects of steaming and dehydration on anthocyanins, antioxidant activity, total phenols and color characteristics of purple-fleshed sweet potatoes (Ipomoea batatas). American Journal of Food Technology, 3(4): 224-234. 